\title{
Peculiarities of thickening of the modern foam base in the acid medium
}

A balanced modern foam system involves the use of various condensation mechanisms that provide a stable structure and satisfactory consumer properties.

Aim. To substantiate the rational concentrations of viscosity modifiers when developing foam agents at pH of 3.5-4.5.

Materials and methods. The foam base developed contains Disodium Laureth-3-Sulfosuccinate, Cocamidopropyl Betain, Coco Glucoside/Glyceryl Oleate, PEG-7 Glyceryl Cocoate, PEG-4 Rapeseedamide, PEG-150 Polyglyceryl-2 Stearate and Laureth-3, purified water. As a pH regulator lactic acid was used; as a preservative the complex containing Triethylene Glycol/Benzyl Alcohol/Propilene Glycol/Methylclorisothiazolinone and Methylisothiazolinone (Nipaguard CMB, "Clariant", "Clariant Produkte (Deutschland) GmbH", Germany). Nipagard CMB provides the activity against gram positive and gram negative bacteria, yeasts and molds, is compatible with anionic, cationic and nonionic surfactants, remains fully stable up to $\mathrm{pH}$ 8. The physical and chemical methods, including structural and mechanical methods, were used. For greater reliability of the experiments and the practical value of the work the samples of the substances studied were provided by the pharmaceutical research center "Alliance of Beauty" (Kyiv, Ukraine).

Results and discussion. The important task when developing foam systems at acidic $\mathrm{pH}$ value is the choice of the complex of viscosity modifiers that would provide stability, easy dosing and the ease of use. The study confirmed the need for introduction of an associative gel former (hydroxypropylmethylcellulose) and electrolyte (sodium chloride).

Conclusions. According to the results of the studies the necessity of introducing a complex of viscosity modifiers has been proven: one of them provides the electrolyte thickening, and another one the associative thickening of the foam base.

Key words: viscosity modifiers; foam base; $\mathrm{pH}$ 3.5-4.5

\section{Л. С.Петровська, Ю. О.Безпала, І. І. Баранова}

\section{Особливості згущення сучасної піномийної основи у кислому середовищі}

Збалансована сучасна піномиюча система включає в себе застосування різних механізмів згущення, які забезпечують стабільну структуру і задовільні споживчі властивості.

Мета. Обґрунтування раціональних концентрацій модифікаторів в'язкості для піномийних засобів при рН 3,5-4,5.

Матеріали та методи. Розроблено піномийну основу (Disodium Laureth-3-Sulfosuccinate, Cocamidopropyl Betain, Coco Glucoside/Glyceryl Oleate, PEG-7 Glyceryl Cocoate, PEG-4 Rapeseedamide, PEG-150 Polyglyceryl-2 Stearate and Laureth-3, вода очищена). В якості регулятора значення рН використовували Lactic Acid, консерванта комплекс: Triethylene Glycol/Benzyl Alcohol/Propilene Glycol/Methylclorisothiazolinone and Methylisothiazolinone (Nipaguard CMB, «Clariant», «Clariant Produkte (Deutschland) $\mathrm{GmbH»,} \mathrm{Німеччина).} \mathrm{«Nipaguard} \mathrm{СМВ»} \mathrm{забезпечує}$ активність проти грампозитивних і грамнегативних бактерій, дріжджів і цвілі, сумісний з аніонними, катіонними і неіоногенними поверхнево-активними речовинами, зберігає стабільність до рН 8. Використовували фрізико-хімічні методи, включаючи структурно-механічні. Для більшої достовірності експериментів та практичного значення роботи зразки досліджуваних речовин були надані фармацевтичним науково-дослідним центром «Альянс Краси» (м. Київ, Україна).

Результати та їх обговорення. Важливим завданням при розробці піномийних систем при кислому значенні $\mathrm{pH} €$ вибір комплексу модифрікаторів в'язкості, які б забезпечили стабільність, легке дозування і зручність застосування. У ході дослідження було підтверджено необхідність введення асоціативного гелеутворювача (гідроксипропілметилцелюлози) та електроліту (натрію хлориду).

Висновки. За результатами проведених досліджень доведена необхідність введення комплексу модифікаторів в'язкості, один з яких забезпечує електролітне, а другий - асоціативне згущення піномийної основи-носія.

Ключові слова: модифрікатори в'язкості; піномийна основа; рН 3,5-4,5

\section{Л. С. Петровская, Ю. А. Беспалая, И. И. Баранова}

\section{Особенности загущения современной пеномоющей основы в кислой среде}

Сбалансированная современная пеномоющая система включает в себя применение различных механизмов загущения, которые обеспечивают стабильную структуру и удовлетворительные потребительские свойства.

Цель. Обоснование рациональных концентраций модификаторов вязкости при разработке пеномоющих средств при $\mathrm{pH} 3,5-4,5$. 
Материалы и методы. Разработана пеномоющая основа (Disodium Laureth-3-Sulfosuccinate, Cocamidopropyl Betain, Coco Glucoside/Glyceryl Oleate, PEG-7 Glyceryl Cocoate, PEG-4 Rapeseedamide, PEG-150 Polyglyceryl-2 Stearate and Laureth-3, вода очищенная). В качестве регулятора значения pH использовали Lactic Acid, консерванта - следующий комплекс: Triethylene Glycol/Benzyl Alcohol/Propilene Glycol/Methylclorisothiazolinone и Methylisothiazolinone (Nipaguard CMB, «Clariant», «Clariant Produkte (Deutschland) GmbH», Німеччина). «Nipaguard СМВ» обеспечивает активность против грамположительных и грамотрицательных бактерий, дрожжей и плесени, совместим с анионными, катионными и неионогенными поверхностно-активными веществами, стабилен до рН 8. Для большей достоверности экспериментов и практического значения работы образцы исследуемых веществ были предоставлены фармацевтическим научно-исследовательским центром «Альянс Красоты» (г. Киев, Украина).

Результаты и их обсуждение. Важной задачей при разработке пеномоющих систем при кислом значении рН является выбор комплекса модификаторов вязкости, которые бы обеспечили стабильность, легкое дозирование и удобство применения. В ходе исследования была подтверждена необходимость введения ассоциативного гелеобразователя (гидроксипропилметилцеллюлозы) и электролита (натрия хлорида).

Выводы. По результатам проведенных исследований доказана необходимость введения комплекса модификаторов вязкости, один из которых обеспечивает электролитное, а второй - ассоциативное загущение пеномойной основы-носителя.

Ключевые слова: модифрикаторы вязкости; пеномоющая основа; pH 3,5-4,5

In foam agents viscosity modifiers are used not only to thicken a multicomponent system, but also to control and provide the long-term structural viscosity of the finished product [1-3].

Currently, among the wide assortment of thickeners three types are used most commonly: inorganic resins (polymeric or cellulose derivatives), and high molecular weight ethoxylates used previously to thicken the foam system. There is a certain complexity of combining viscosity modifiers with a mixture of the primary foaming surfactants and "soft" secondary surfactants, which, in turn, affects the technological process of producing a foam agent $[4,5]$.

The aim of our work was to substantiate the rational concentrations of viscosity modifiers when developing foam agents at $\mathrm{pH}$ of 3.5-4.5.

\section{Materials and methods}

By our previous studies the foam base with modern detergents (Disodium Laureth-3-Sulfosuccinate, Cocamidopropyl Betain, Coco Glucoside/Glyceryl Oleate, PEG-7 Glyceryl Cocoate, PEG-4 Rapeseedamide, PEG-150 Polyglyceryl-2 Stearate and Laureth-3, purified water) was developed and substantiated [6-9]. As a pH regulator lactic acid was used; as a preservative the complex containing Triethylene Glycol/Benzyl Alcohol/Propilene Glycol/Methylclorisothiazolinone and Methylisothiazolinone (Nipaguard CMB, "Clariant", "Clariant Produkte (Deutschland) GmbH", Germany). Nipagard CMB provides the activity against gram positive and gram negative bacteria, yeasts and molds, is compatible with anionic, cationic and nonionic surfactants, remains fully stable up to pH $8[10,11]$.

Determination of rheological indicators was carried out on a Brookfield DV-II + PRO (USA) viscometer using a rotary adapter with the system of coaxial cylinders. The coaxial geometry of the viscometer consists of a cylindrical spindle and a cylindrical chamber that provide an accurate control of measurement of the rheological parameters of the Newtonian fluids.

The $\mathrm{pH}$ value of the foam samples studied was determined potentiometrically (DFU 1.2, 2.2.3) using a $\mathrm{pH}$ meter Metrohm 744 (Germany) [12].
These studies were conducted at the premises of the research laboratory of the Department of Commodity Science at the National Pharmaceutical University.

The experimental samples of foam bases were prepared taking into account the following technological parameters:

- dissolution of detergents was carried out in the temperature range from 35 to $45^{\circ} \mathrm{C}$ for $10-20 \mathrm{~min}$;

- the mixer rate - up to $40 \mathrm{rpm}$ (to prevent formation of a foam mass);

- the $\mathrm{pH}$ value was adjusted up to 3.5-4.5 using lactic acid.

For greater reliability of the experiments and the practical value of the work the samples of the substances studied were provided by the pharmaceutical research center "Alliance of Beauty" (Kyiv, Ukraine).

\section{Results and discussion}

Taking into account that when developing a foam base only detergents of the "soft" action were used it led to impossibility of achieving a suitable viscosity with the help of a classical, affordable and effective type of a thickener - electrolytes (sodium or ammonium chloride). Therefore, at the first stage of our studies concerning thickening we selected effective gel formers at the given $\mathrm{pH}$ range (3.5-4.5) considering the direction and the application site of the finished foam agent. The following substances were used: Hydroxypropyl Methylcellulose ("METHOCEL 40-0100", "Dow", Germany) contributing to the condensation of the system and formation of fine-grained long-lasting foam; Xanthan forming gel bases resistant to changes in $\mathrm{pH}$ and high temperatures; Cetheart-10 allyl ether/acrylic copolymer ("Salcare SC 80", "Ciba", Switzerland). The recommended concentrations of gel formers when developing foam agents for intimate hygiene with acidic $\mathrm{pH}$ values were from 0.1 to $0.5 \%[13,14]$.

The gel bases with the above-mentioned polymers were prepared according to the generally accepted technologies [15-18] and added to the base prepared at room temperature and adjusted the $\mathrm{pH}$ value to the $\mathrm{pH}$ of 3.5-4.5 using lactic acid.

It was found that with addition of all gel formers in the concentrations from 0.1 to $0.5 \%$ a gradual increase 


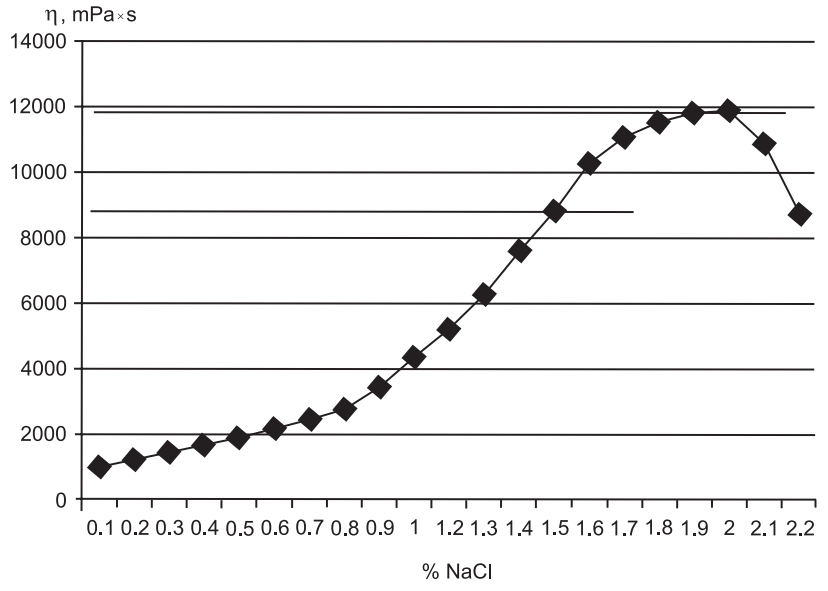

Fig. The dependence of the structural viscosity (at $20 \mathrm{rpm}$ ) on the concentration of the electrolyte

in the structural viscosity was observed. The samples based on "Salcare SC 80" revealed the highest viscosity values (12340 to $17650 \mathrm{mPa} \times \mathrm{s}$ at $20 \mathrm{rpm})$. It should be noted that they were stable, but did not have satisfactory rheological characteristics (no fluidity of the system was observed). The samples, which used Xanthan as a thickener, also had a high viscosity (from 12100 to $14280 \mathrm{mPa} \times \mathrm{s}$ at $20 \mathrm{rpm}$ ); in addition, within the course of 30 days, the stratified systems were observed.

During this experiment it was noted that the samples with the concentration of HPMC from 0.3 to $0.5 \%$ had an excessively high degree of thickening of the system (from 12300 to $16450 \mathrm{mPa} \times \mathrm{s}$ at $20 \mathrm{rpm}$ ) and did not meet the recommended standards for intimate hygiene products (the structural viscosity value should be in the range of 2000-12000 $\mathrm{mPa} \times \mathrm{s}$ ). Analyzing the results of the experiments with the samples with the concentration of GMPT of 0.1 and $0.2 \%$ it was found that they both had the necessary viscosity characteristics, therefore, from the economic point of view, the concentration of GMPP of $0.1 \%$ was selected.

The base obtained had some signs of stability, however, it did not exhibit the necessary viscosity value (the system should additionally exhibit the property of fluidity, being one of the requirements of the consumer characteristics of the finished gel for the intimate zones of the human body.

Taking into account the above facts $10 \%$ (or $25 \%$ ) solution of sodium chloride was added to our samples. The expediency of introducing the electrolyte solution is associated with prevention of formation of high local concentrations, which, in turn, can lead to appearance of gelling. The electrolyte solution was introduced in the last turn after cooling the foam base at room temperature to set a rational concentration. In further studies solutions of sodium chloride in the concentration up to $1.5 \%$ were used. As can be seen from Fig., an increase to the maximum viscosity of $12.000 \mathrm{mPa} \times \mathrm{s}$ was observed.
This is due to the interaction of an electrolyte with long-chain molecules of the anionic detergent (Disodium Laureth-3-Sulfosuccinate), which leads to an increase in the ion fixation density. Usually, it is advisable to introduce a salt with the same ion as the main detergent has. The use of an electrolyte allows shifting the balance: micelles having a spherical structure are transformed into micelles with a cylindrical structure. Further, cylindrical micelles are not able to move freely relative to each other like spherical ones. Due to this there is an increase in the structural viscosity and the possibility of correction of the consistency of the foam agent.

As can be seen from Fig., as a result of our research the system of components, in which the viscosity level required is located on the central segment of the emerging line and is characterized by a curved curve, have been obtained. Thus, it has been experimentally proven that the optimal concentration of sodium chloride is in the range of 1.5 to $2.0 \%$. It should be noted that in the laboratory samples obtained the electrolyte concentration of $1.5 \%$ is used to achieve the recommended viscosity (from 9000 to $12000 \mathrm{mPa} \times \mathrm{s}$ at $20 \mathrm{rpm}$ ), but in samples manufactured in industrial conditions it will be $1.6 \%$. In order to adapt to the industrial conditions of production the expediency of introducing an electrolyte in the last turn in parts is recommended since complete achievement of the equilibrium with the ingredients of the foam base requires a certain amount of time. The excessive introduction of sodium chloride solution can lead to instantaneous dilution of the system and opacity of the gel.

\section{CONCLUSIONS}

According to the results of the studies the necessity of introducing a complex of viscosity modifiers has been proven: one of them provides the electrolyte thickening, and another one the associative thickening of the foam base. It has been experimentally determined that as an associative thickener it is rational to introduce hydroxypropylmethylcellulose ("Methocel 40-0100", "Dow", Germany) in the concentration of $0.1 \%$, which contributes to formation of a fine-grained foam. Moreover, it is advisable to use the solution of sodium chloride (10\%) in the concentration of $1.5-2.0 \%$, which leads to an increase in density due to electrolytic condensation, and additionally prevents creation of local concentrations that can lead to gelling. The foam base developed is a complex and balanced system, which combines various mechanisms of thickening to achieve the necessary structural and mechanical properties. This has been achieved due to the combination of detergents of different nature, and introduction of the complex of viscosity modifiers (polymer and electrolyte). Thus, it has been proven that the viscosity modifiers selected provide the finished product with the necessary extrusion properties, and also affect the stability of the foam agent.

Conflict of Interests: authors have no conflict of interests to declare. 


\section{REFERENCES}

1. Zana, R. Gemini Surfactants : Synthesis, Interfacial and Solution-Phase Behavior, and Applicalions / R. Zana, J. Xia. - New York : Marcel Dekker, 2004. - 345 p.

2. Surfactants in the management of rhinopathologies / P. L. Rosen, J. N. Palmer, B. W. O’Malley, N. A. Cohen // Am. J. Rhinol. Allergy. 2013. - Vol. 27, Issue 3. - P. 177-180. doi: 10.2500/ajra.2013.27.3873

3. Лейдрейтер, Г. Использование синергизма в смесях сурфактантов / Г. Лейдрейтер, У. Мацкевич, М. Шмидт // Косметика \& Медицина. - 1998. - № 1. - С. 21-26.

4. Поверхностно-активные вещества и композиции / под ред. М. Ю. Плетнева. - М. : Фирма Клавель, $2002 .-768$ с.

5. Плетнев, М. Ю. Косметико-гигиенические моющие средства / М. Ю. Плетнев. - М. : Химия, 1990. -456 с.

6. Петровська, Л. С. Розробка та вивчення технологічних, фізико-хімічних властивостей піномійних основ 3 кокамідопропілбетаїном при значенні $\mathrm{pH} 3,8$ - 4,8 / Л. С. Петровська // Управління, економіка та забезпечення якості в фармації. - 2015. № 1 (39). - C. 14-18.

7. Петровська, Л. С. Розробка основи з сучасними сурфактантами / Л. С. Петровська, І. І. Баранова // Актуальні питання наукової та практичної косметології : матер. Всеукр. наук.-практ. конф. з міжнар. участю, 17-18 квіт. 2014 р., м. Запоріжжя. - Запоріжжя : ЗДМУ, 2014. - С. 51-52.

8. Research indicators of foaming ability magnesium laurethat from different $\mathrm{pH}$ values / L. S. Petrovskaya, I. I. Baranova, Y. O. Bezpala, C. M. Kovalenko // Asian J. of Pharmac. - 2017. - Vol. 11, Issue 1. - P. 187-190.

9. Петровська, Л. С. Порівняльна характеристика фізико-хімічних показників низки сучасних детергентів при розробці піномийних основ / Л. С. Петровська // Управління, економіка та забезпечення якості в фармації. - 2016. - № 4 (48). - С. $21-24$.

10. Беликов, О. Е. Консерванты в косметике и средствах гигиены / О. Е. Беликов, Т. В. Пучкова. - М. : Школа косметических химиков, 2003. $-250 \mathrm{c}$.

11. Gray, J. E. Preservatives - their role in cosmetic products / J. E. Gray, P. M. McNamee // Sci. Review Series. - 2000. - Vol. 1, Issue 2. P. $38-49$.

12. Державна фармакопея України / Державне підприємство «Науково-експертний фармакопейний центр». - 1-е вид., 2. доп. - X. : РІРЕГ, 2008.

13. Handbook of Cosmetic Science and Technology / ed. A. O. Barel, M. Paye, H. I. Maibach. - New York : Marcel Dekker, 2001. - 902 p.

14. Multifunctional Cocmetic / ed. R. Shueller, P. Romanowski. - Cambridge : Cambridge University Press, 2003. - 248 p.

15. Баранова, I. І. Порівняльне дослідження структурно-механічних параметрів ряду лікарських та косметичних гелів 3 метою визначення реологічного оптимуму / I. І. Баранова, Н. П. Половко // Поглед върху световната наука - 2010 : матер. VI Междунар. науч.-практ. конф., София, 17-25 дек. 2010 г. - София, 2010. - С. 6-8.

16. Баранова, И. И. Сравнительная характеристика реопараметров гелеобразователей различного происхождения / И. И. Баранова, С. Н. Запорожская // Запорожский мед. журн. - 2008. - № 4. - С. 81-84.

17. Баранова, I. І. Вивчення фізико-хімічних та структурно-хімічних властивостей гідрогелів на основі полімерної композиції «Salcare-80» / I. І. Баранова // Укр. журн. клін. та лабораторної медицини. - 2009. - Т. 4, № 1. - С.16-18.

18. Rosen, R. M. Delivery System Handbook for Personal Care and Cosmetic Products, Technology, Applications and Formulations / R. M. Rosen. Norwich; New York : William Andrew Publishing, 2005. - 423 p.

\section{REFERENCES}

1. Zana, R., Xia, J. (2004). Gemini. Surfactants: Synthesis, Interfacial and Solution-Phase Behavior, and Applicalions. New York: Marcel Dekker, 345.

2. Rosen, P. L., Palmer, J. N., O’Malley, B. W., Cohen, N. A. (2013). Surfactants in the management of rhinopathologies. American Journal of Rhinology and Allergy, 27 (3), 177-180. doi: 10.2500/ajra.2013.27.3873

3. Leidreiter, G., Matckevich, U., Shmidt, M. (1998). Kosmetika \& Meditcina, 1, 21-26.

4. Pletnev, M. Yu. (2002). Poverkhnostno-aktivnye veshchestva i kompozitcii. Moscow: Firma Klavel, 768.

5. Pletnev, M. Yu. (1990). Kosmetiko-gigienicheskie moiushchie sredstva. Moscow: Khimiia, 456.

6. Petrovska, L. S. (2015). Upravlinnia, ekonomika ta zabezpechennia yakosti v farmatsii, 1 (39), 14-18.

7. Petrovska, L. S., Baranova, I. I. (2014). Aktualni pytannia naukovoi ta praktychnoi kosmetolohii. Zaporizhzhia: ZDMU, 51-52.

8. Petrovskaia, L. S., Baranova, I. I., Bezpala, Y. O., Kovalenko, C. M. (2017). Research indicators of foaming ability magnesium laurethat from different $\mathrm{pH}$ values. Asian Journal of Pharmaceutics, 11 (1), 187-190.

9. Petrovska, L. S. (2016). Upravlinnia, ekonomika ta zabezpechennia yakosti v farmatsii, 4 (48), $21-24$.

10. Belikov, O. E., Puchkova, T. V. (2003). Konservanty v kosmetike i sredstvakh gigieny. Moscow: Shkola kosmeticheskikh khimikov, 250.

11. Gray, J. E., McNamee, P. M. (2000). Preservatives - their role in cosmetic products. Scientific Review Series, 1 (2), 38-49.

12. DP «Naukovo-ekspertnyi farmakopeinyi tsentr». (2008). Derzhavna Farmakopeia Ukrainy (1st ed.). Kharkiv: RIREH.

13. Barel, A. O., Paye, M., Maibach, H. I. (2001). Handbook of Cosmetic Science and Technology. New York: Marcel Dekker, 902.

14. Shueller, R., Romanowski, P. (Eds.). (2003). Multifunctional Cocmetic. Cambridge: Cambridge University Press, 248.

15. Baranova, I. I., Polovko, N. P. (2010). Pohled verkhu svetovnata nauka. Cofiia, 6-8.

16. Baranova, I. I., Zaporozhskaia, S. N. (2008). Zaporozhskii meditcinskii zhurnal-Zaporozhye Medical Journal, 4, 81-84.

17. Baranova, I. I. (2009). Ukrainskyi zhurnal klinichnoi ta laboratornoi medytsyny, 4 (1), 16-18.

18. Rosen, R. M. (2005). Delivery System Handbook for Personal Care and Cosmetic Products, Technology, Applications and Formulations. Norwich; New York: William Andrew Publishing, 423. 


\section{Information about authors:}

Petrovska L. S., Candidate of Pharmacy (Ph.D), associate professor of the Department of Cosmetology and Aromology, National University of Pharmacy.

E-mail: 1.s.petrovskaya96@gmail.com. ORCID: http:orcid.org/0000-0003-4914-9650

Bezpala Yu. O., Candidate of Pharmacy (Ph.D), teaching assistant of the Department of Commodity Science, National University of Pharmacy.

E-mail: yuliyabespalaya5@gmail.com. ORCID: http:orcid.org/0000-0002-0077-8934

Baranova I. I., Doctor of Pharmacy (Dr. habil), head of the Department of Commodity Science, National University of Pharmacy.

E-mail: innabaranovapharm@ukr.net. ORCID: http:orcid.org/0000-0003-2827-265X

Відомості про авторів:

Петровська Л. С., канд. фарм. наук, доцент кафедри косметології і аромології, Національний фармацевтичний університет.

E-mail: 1.s.petrovskaya96@gmail.com. ORCID: http: orcid.org/0000-0003-4914-9650

Безпала Ю. О., канд. фарм. наук, асистент кафедри товарознавства, Національний фармацевтичний університет.

E-mail: yuliyabespalaya5@gmail.com. ORCID: http: orcid.org/0000-0002-0077-8934

Баранова I. I., д-р фарм. наук, професор, завідувач кафедри товарознавства, Національний фармацевтичний університет.

E-mail: innabaranovapharm@ukr.net. ORCID: http: orcid.org/0000-0003-2827-265X

Сведения об авторах:

Петровская Л. С., канд. фарм. наук, доцент кафедры косметологии и аромалогии, Национальный фармацевтический университет.

E-mail: 1.s.petrovskaya96@gmail.com. ORCID: http:orcid.org/0000-0003-4914-9650

Беспалая Ю. А., канд. фарм. наук, ассистент кафедры товароведения, Национальный фармацевтический университет.

E-mail: yuliyabespalaya5@gmail.com. ORCID: http:orcid.org/0000-0002-0077-8934

Баранова И. И., д-р фарм. наук, профессор, заведующая кафедрой товароведения, Национальный фармацевтический университет.

E-mail: innabaranovapharm@ukr.net. ORCID: http:orcid.org/0000-0003-2827-265X 